\title{
Understanding the Relation of Policy Discourse and Re- Conceptualising Curriculum: A Kosovo Perspective on a New Meaning of Context
}

\section{BLeRIM SAQIPI ${ }^{1}$}

$\approx$ This article is an analysis of the meaning of context in implementing curriculum reform. It uses an analysis of two Kosovo curriculum reforms in the previous two decades to elaborate on how education systems engage in the transfer of transnational ideas as well as how they face challenges in making those ideas succeed. The article uses Discursive Institutionalism and the debate between the Didaktik and Curriculum Theory Traditions as a framework for analysis to understand the form of ideas and types of discourses that are relevant for successful curriculum reform. While the Kosovo curriculum reform has been struggling to find a balance between the Didaktik and Curriculum Theory Traditions, it is evident that two reform projects did not provide sufficient possibilities for coordinative discourse among key actors in the reform implementation. For reform to succeed, education systems need to balance between both background and foreground ideas as well as communicative and coordinative discourses. In education systems whose professional capacities are limited and whose resources are scarce, such a balance gains greater importance, indicating the need for more school-based development activities. Therefore, the context should not be viewed as solely static, but needs to be assigned a new meaning regarding what it is and should be placed at the service of reform implementation by recognising the importance of critical reflection when adopting a particular curriculum policy orientation and tailoring the discourse for promoting reform ideas.

Keywords: policy discourse, curriculum theory, context, Kosovo, discursive institutionalism, Didaktik curriculum reform 


\section{Razumevanje povezave med političnim diskurzom in novim konceptom kurikuluma: pogled Kosova na spremenjen kontekst}

\section{BLERIM SAQIPI}

$\approx$ V članku je analiziran pomen konteksta izvajanja kurikularne prenove. Gre za analizo dveh kurikularnih prenov v zadnjih dveh desetletjih na Kosovem, katere namen je pojasniti način vključevanja izobraževalnih sistemov $\mathrm{v}$ prenos transnacionalnih idej in spoprijemanja $\mathrm{z}$ izzivi pri uresničevanju teh idej. V članku sta prikazana diskurzivni institucionalizem ter razprava o tradicionalni teoriji didaktike in kurikularni teoriji kot okvir za analizo razumevanja oblikovanja idej in vrst diskurzov, ki so pomembni za uspešno kurikularno prenovo. Medtem ko si kurikularna prenova na Kosovem prizadeva vzpostaviti ravnovesje med tradicionalnima teorijama didaktike in kurikuluma, je očitno, da ta reformna projekta nista omogočila usklajenega diskurza med ključnimi akterji izvedbe prenove. Za uspeh reforme je nujno, da izobraževalni sistemi uravnovesijo neizpostavljene pa tudi izpostavljene ideje ter komunikacijske in koordinativne diskurze. V izobraževalnih sistemih, katerih profesionalne zmogljivosti in sredstva so omejena, narašča pomen tovrstnega ravnovesja in posledično se povečuje potreba po razvojnih dejavnostih $\mathrm{v}$ šolah. Zato konteksta ne bi smeli obravnavati kot izključno statičnega, ampak mu je treba pripisati drugačen pomen glede na njegov položaj glede omogočanja izvajanja reform; prav tako mu je treba priznati pomen kritične refleksije pri sprejemanju določene usmeritve kurikularne politike in prilagajanju diskurza za spodbujanje reformnih idej.

Ključne besede: politični diskurz, kurikularna teorija, kontekst, Kosovo, diskurzivni institucionalizem, didaktika, kurikularna reforma 


\section{Introduction}

Though curriculum policy is considered a national matter, it is not resistant to transnational policies or the policy transfer phenomenon. The transnational policy flow takes different forms in various countries due to the specific historical, social, and cultural traditions (Wahlstrom \& Sundberg, 2017). Correctly, research on policy borrowing or policy transfer indicates the need to pay attention to policy re-contextualisation or translation into local context (Steiner-Khamsi, 2012; Wahlstrom \& Sundberg, 2017) as it matters where the new idea is introduced and how it is internalised and resourced. Currently, the debate on education policy-making is centred around how policies are shaped, from where reform efforts originate, and how they are re-contextualised. In this regard, the process of policy borrowing has gained greater attention over the last two decades, owing to the increasing focus of education systems internationally on identifying and learning from good practices and models.

Studying curriculum policy can be focused on the values and orientation it prescribes and examining how ideas are taken forward or how the planned curriculum is implemented and delivered at classroom level. When instituting a curriculum reform, it is critical that education systems address the vital aspect of why some ideas succeed or fail to be translated into classroom-level changes. In understanding the reasons for that, there is a need to understand the real meaning and value attached to the diverse contextual variables that play a role in this. As common as they are, the contextual variables are still specific, and they deserve attention in the implementation of both nationally driven policies and policies transferred from elsewhere.

Kosovo education operated under the repressive regime of Serbia until 1999 and for a decade education had been banned for the majority Albanian population. In circumstances in which education provision was merely a survival tool, issues such as curriculum development and reform were not on the agenda. With the establishment of Kosovo-run institutions under the then international administration led by the United Nations in 1999, Kosovo started to place education reform on its list of priorities. The curriculum reform was one of those, and a new curriculum policy was formally introduced in 2001. The 2001 Curriculum Framework aimed to shift the focus from teacher-centeredness to more learner-centred constructivist approaches to teaching and learning; however, the core curriculum remained content-focused with learning objectives defined per topic within individual subjects and no efforts were made to generate either general or specific standards or competencies (Tahirsylaj, 2018). 
To advance towards a learner-centred practice and outcomes-based approach in teaching and learning, Kosovo revised the 2001 curriculum by adopting a new competence-based curriculum in 2011. The $2011 \mathrm{KCF}$ ("MEST", 2011) emphasises the need to organise teaching and learning around a core set of competencies, which interrelate with the European Union 2006 competencies:

- Communication and expression competencies - Effective communicator

- Thinking competencies - Creative thinker

- Learning competencies - Successful learner

- Life, work, and environment-related competencies - Productive contributor

- $\quad$ Personal competencies - Healthy individual

- $\quad$ Civic competencies - Responsible citizen

Furthermore, the purpose of education, according to the new $2011 \mathrm{KCF}$, is:

- $\quad$ Cultivating the personal and national, state and cultural identity;

- $\quad$ Promotion of the general cultural and citizenship values;

- Developing responsibility towards oneself, towards others, society and environment;

- $\quad$ Developing entrepreneurship and use of technology;

- Developing life-long learning skills.

This study provides an in-depth view of understanding the contextual dimension of curriculum policy to determine the challenges that influence the success or failure of reform policies. The article is an analysis of the Kosovo curriculum reform process in the previous two decades - two significant reform efforts that span over last 20 years (initiated in 2001 and 2011) - which have interacted with the challenges of the education system in one hand and the trends of following specific external policy models on the other. Kosovo is an example of a state undergoing transition from a post-communist and post-conflict context into a democracy, market-oriented environment and a society aspiring to integration in European structures and beyond. Curriculum reform has been projected as a major reform effort to address the specifics of the country in light of this particular context. However, how the system has determined its curriculum policy orientation - in interaction with various curriculum traditions - and the challenges that obstruct the success of reform ideas are not known. Currently, there is an understanding that two curriculum reform projects in Kosovo have failed to move professionals and professionalism in the education system forward and consequently have failed to increase student learning (See "MEST", 2016; Saqipi, 2014). 
Empirical evidence on the recently completed piloting of the new curriculum is scant; this study draws on the larger research project of analysing Kosovo's education policy orientation and the author's experience in Kosovo education policymaking in the previous two decades. The study uses the two curriculum policies (2001 and 2011) as a unit of analysis to determine the policy orientation - along the lines of debate between the Didaktik and Curriculum Theory traditions (Hopmman, 2007; Hopmann \& Riquarts, 2000) and the Ministry of Education, Science and Technology (MEST) work plans and reports as data to analyse implementation practice for the 2011 curriculum implementation through the framework of Discursive Institutionalism (Wahlstrom \& Sundberg, 2017). The study is further structured around analysing the shift in orientation as Kosovo was transiting from the 2001 to the 2011 curriculum reform, which are critical contextual factors that were significant during the initial reform implementation as a way to understand the challenges that are deemed essential for curriculum reform implementation.

\section{Importance of conceptualising curriculum policy}

One way of analysing curriculum policy is to look at the dimensions of planning the curriculum, implementing it, and what students learn and experience. Goodlad et al. (1979) identified five domains of curricula. According to Goodlad et al. $(1979,61)$ when the five domains of the curricula are analysed 'one finds those beliefs, values, attitudes, and the like which society or some dominant group in society wishes the young to acquire. Although these domains are extensive and open to different possible interpretations, they have been useful in the general analysis of the different processes of the curricula in various contexts, at a theoretical and practical level. Therefore, in any curriculum design process, in addition to ideological and political orientation it is also essential to determine what actually goes to schools as formal curriculum, how teachers and other stakeholders perceive the curriculum, how teachers operationalise the curriculum in schools and how students engage with the curriculum implementation (See Table 1 for a summary of different domains). This is also known as intended, enacted, and achieved curriculum (Anderson-Levitt, 2008) to reflect the three critical dimensions of curriculum. 
Table 1

Five Domains of the Curriculum

\begin{tabular}{|c|c|}
\hline Domains & Definition of domains \\
\hline Ideological Curriculum & The abstract political and socio-political level of curricula \\
\hline Formal Curriculum & $\begin{array}{l}\text { A curriculum that has gained official approval by the state and exists } \\
\text { in written form }\end{array}$ \\
\hline Perceived Curriculum & $\begin{array}{l}\text { The perception of other stakeholders such as parents, teachers, learn- } \\
\text { ers and politicians about what the curriculum should be }\end{array}$ \\
\hline Operational Curriculum & The teaching and learning activities in the classroom and the school \\
\hline Experiential Curriculum & $\begin{array}{l}\text { The learner's experience and their cognitive, emotional and social, } \\
\text { practical and experimental processes }\end{array}$ \\
\hline
\end{tabular}

Note. Adapted from Goodlad et al., 1979.

The two curriculum reforms in Kosovo have followed the same logic elaborated in Table 1 above. They are meant to be a driving force to support the development of a society that nurtures Western values and develop the skills that are currently demanded for economic and societal development. During the experience of implementing two curriculum reform projects in the last two decades in Kosovo, we can conclude that the critical levels of the curriculum process are the operational and experiential levels, given the challenges faced with in enacting changes at the classroom level (see "MEST", 2016). In other words, how we deliver and how we get students to engage with the curriculum implementation are of critical importance because this makes the difference. The focus of curriculum reform in Kosovo was placed at how teachers act in the classroom and instructions for new curriculum implementation were meant to drive the expected teacher change forward. However, what Kosovo failed to sufficiently address is the way teachers interpret, internalise, and operationalise a curriculum policy.

Connected with the ideological and formal domain of the curriculum, the policy transfer phenomena certainly influences policy discourse at the national level. On a regular basis, education systems struggle to determine their approach to shaping certain policies and curriculum policy area is no exception. The two curriculum reform projects in Kosovo are characterised by an attempt to follow transnational trends in curriculum policy discourse. However, it is hard to say how or what Kosovo has learned from the transnational debates in curriculum policy since there is no written reference to indicate whether curriculum reform was meant to intentionally adopt certain policy inputs from a specific tradition or orientation, though there is evidence of reference models that were taken from European countries. It has been more a matter of policy influence of certain actors, which mainly appeared to be international donors 
and policymakers supporting post-conflict Kosovo by promoting specific policy frameworks, such as UNICEF, UNESCO, and the World Bank (Saqipi, 2014).

One can analyse the Kosovo trajectory of curriculum policy shaping through the frames of the ongoing debate on the dichotomy between Didaktik Theory and Curriculum Theory. The German Didaktik theory is central to curriculum policies in Continental Europe generally and the German-speaking world specifically, as well as in Nordic countries (Tahirsylaj, 2018b). Being in Europe, Kosovo's curriculum thinking had been influenced in earlier times from the Didaktik tradition if we review the curriculum documents of 2001 (see "MEST", 2001) and before. This was done partly due to the cultural model of policy transfer (see Steiner-Khamsi, 2013), in the context of the cooperation of academics and the easy flow of ideas within Europe.

Curriculum Theory, in contrast, is a widely used theory amongst many countries, primarily in the English-speaking world (Hopmann, 2007). Table 2 below presents a summary of the characteristics of Didaktik Theory and Curriculum Theory in relation to the theory and practice of teachers as well as education research. The key term in understanding Didaktik Theory is 'Bildung', which implies the need to focus on child formation rather than the achievement of specific pre-determined outcomes and skills (Hopmann, 2007; Hopmann \& Riquarts, 2000). Westbury (2000) characterised the Curriculum Theory tradition as being focused at the organisational level or otherwise known as 'curriculum-as-manual' (Autio, 2014) as a tool to guide, shape and control what goes on in school. Though in any curriculum tradition, education systems have some sort of plan that outlines the goals and content, the difference is in how the education system and its actors conceptualise and operationalise it in view of the roles of teachers and purposes of schooling.

\section{Table 2}

Didaktik and Curriculum Theory compared

\begin{tabular}{|c|c|c|}
\hline Level & Curriculum & Didaktik \\
\hline \multicolumn{3}{|l|}{ Lesson planning } \\
\hline Core question & How & What and why \\
\hline Content as & Object & Example \\
\hline Lesson plan as & Task & Goal (direction) \\
\hline \multirow[t]{2}{*}{ Teaching as } & Course action & Frames of reference \\
\hline & Enactment & Licensed \\
\hline \multicolumn{3}{|l|}{ Research } \\
\hline$\overline{\text { Focus }}$ & $\begin{array}{l}\text { Individual teacher } \\
\text { Teacher thinking } \\
\text { (interpretative) }\end{array}$ & $\begin{array}{l}\text { Art of teaching, Didaktik } \\
\text { analysis (hermeneutic) }\end{array}$ \\
\hline $\begin{array}{l}\text { Assessment of successful } \\
\text { teaching }\end{array}$ & $\begin{array}{l}\text { Student achievement } \\
\text { (scores \& standing) }\end{array}$ & $\begin{array}{l}\text { Professional appropriate- } \\
\text { ness, reflection }\end{array}$ \\
\hline
\end{tabular}




\begin{tabular}{lll}
\hline Level & Curriculum & Didaktik \\
\hline$\underline{\text { Theory }}$ & Preparation & Initiation \\
function & Subject matter comes \\
sequence & Bildung comes first \\
& & \\
\hline
\end{tabular}

Note. Adapted from Westbury, Hopmann, \& Riquarts, 2000.

The two traditions have argued over the role of teachers, autonomy, and approaches to curriculum conceptualisation and delivery. In principle, the Didaktik and Curriculum Tradition do not differ much at first glance. They address the same matters of the role of the content, definition and meaning of teaching goals, the ways learning results are evaluated, etc. (Westbury, 2000). There is significant overlap between the two, and one can tell that there has been influence from both directions in the way curriculum and teaching is perceived and delivered in both traditions. So, the difference is noticed more at the operational and experiential levels. Many education systems may find themselves in policy discourses about this or drawing on both traditions unintentionally or owing to how they engage with policy transfer phenomenon.

Analysing Kosovo curriculum reform projects of the last two decades, it can be considered that curriculum policy has been seen as a tool for the state to control the development of the education system (Saqipi, 2019). In 2001, Kosovo introduced a new curriculum: the first after decades of difficult circumstances of school operation and overall functioning of the society. In the situation of restoring peace and democracy in Kosovo after 1999, when the war ended, it was justifiable that Kosovo, under the supervision of the international community (Kosovo was administered by the United Nations in the period from 1999 until 2008, when it declared independence), opted for a curriculum policy that is detailed and installed state control in terms of content and suggestions for teacher instructional decision, which almost reached the stage of ready-made models to be executed. In addition, the Kosovo education system started to place more emphasis on external standardised testing. In such circumstances of post-war revival in which teachers lacked the opportunities to access professional development activities and teacher education had been conducted under limited resources and insufficient quality (Saqipi, 2014; Saqipi \& Vogrinc, 2017), taking a more centralised approach to curriculum implementation was considered adequate and expected. In general, the research identifies the challenges for teacher education to prepare teachers well for the realities of school (Brouwer \& Korthagen, 2005; Darling-Hammond, 2000; Huang, 2016), while this theory-practice gap becomes even more relevant when a new ambitious reform is introduced. In the Kosovo school system, the capacities at the school 
level (including resource availability and teacher and director professional capacities) had been too limited to undertake activities around designing and interpreting curricula (Saqipi, 2019).

Therefore, the Kosovo education system considered it more appropriate to adopt centrally designed detailed curricula that teachers will follow during their routine work without the need to engage in curriculum design in greater depth. This was also occurring in line with the ever-increasing trends of countries around the world adopting performativity agendas, otherwise known as 'standardisation in education' or 'results-based approach', which place a high focus on accountability policies and uniformity in education system (Day, 2002; Hargreaves \& Shirley, 2009; Helsby, 1999; Sahlberg, 2007, 2011; Smeed et al., 2015). Looking in a greater depth where Kosovo stands in between the Didaktik and Curriculum Theory traditions, there has been no formal analysis to determine which of the two streams has dominated in shaping curriculum policy in Kosovo in the last two decades. However, analysing curriculum policy documents of 2001 ("MEST", 2001) and, more strongly 2011 curriculum policy ("MEST", 2011), one can conclude that Kosovo has embraced Curriculum Theory reasoning. This can be seen in the orientation of centrally prescribed curricula, focus on detailed learning outcomes, administrators determining teaching strategies and lack of expectation for teachers to demonstrate autonomous professionalism by undertaking initiatives at the school level for creating materials, adapting to student development, and deciding on innovative assessment strategies for student learning. More specifically, the 2011 curriculum policy was driven by the philosophy of competency-based curricula. This approach, in practice, overshadowed the critical agenda of the social and emotional development of young people, which has been present in the discussion but only slightly in the actions related to curriculum implementation ("MEST", 2011, 2016).

The two curriculum reform projects in Kosovo were supported by the technical assistance of various donor projects and, in light of the inclination to align the education system to the various international models, it is clear that the Kosovo curriculum reform was not driven by an internal professional motivation to change the situation on the ground. It was more a persistence of a recently established state to follow the good models and practices from various education systems. A valid question, however, remained: whether the reform projects have moved towards the achievement of the desired success. In such a situation of transferring policy ideas, the question of why some ideas succeed while some good ideas fail to do so remains (Wahlstrom \& Sundberg, 2017). Wahlstrom and Sundberg (2017) suggest Discursive Institutionalism (DI) as a model of analysing the reasons behind the failure or success of the ideas. 


\section{Analysing Kosovo curriculum reform projects to under- stand the meaning of context}

Research on policy transfer and implementation recognises the need to pay attention to the context in which the policy is implemented (Steine-Khamsi, 2012; Wahlstrom \& Sundberg, 2017). However, there is a need to understand the meaning of context and determine the variables that are particularly important in making ideas succeed. The concept of Discursive Institutionalism (DI) originated from the work of Vivien Schmidt (2008) who introduced the concept as a reaction to the three traditional institutional approaches (i.e., rational choice, historical and sociological). Schmidt used DI in political science to understand ideas and discourses in much more thorough terms by looking at how global policies are translated into the local context (see Schmidt, 2008, 2009, 2010). DI emphasises the need to determine whether the policy discourse is coordinative (among policy actors) or communicative (between policy actors and the public).

In contrast, DI looks at ideas in policy implementation as being background ideas (underlying assumptions) and foreground ideas (conscious perceptions). Ideas can be cognitive and normative. According to Wahlstrom and Sundberg (2017), normative background ideas are unspoken thoughts on values that fit within the public philosophy, while cognitive background ideas are called paradigms on child learning and purposes of schooling. In contrast, the foreground ideas are more visible and normative ideas and related usually to ideas at the programmatic level on what constitutes the minimum student learning for a particular level of schooling. Cognitive foreground ideas relate to programmatic debate, usually in order to solve various cognitive problems, such as the structure and content of curriculum (Wahlstrom \& Sundberg, 2017).

Wahlstrom and Sundberg (2017) used DI in combination with Curriculum Theory to develop a framework for analysing the relationship between policy and curriculum. In other words, this framework directs the focus towards understanding policy ideas at the societal, programmatic, municipal, and school levels against the specifics of ideas and discourses. A similar framework is adopted for this study (See Table 3 below) to analyse the Kosovo curriculum reform implementation in order to provide a deeper look into important contextual elements that play a critical role in determining the success or failure of reform ideas. This analysis of the Kosovo curriculum reform intends to (i) determine the type and form of ideas needed in curriculum reform implementation, (ii) establish the main forms and functions of the discourse, and (iii) determine the important actors and their roles. 
Table 3

Understanding the Kosovo curriculum reform through different levels, ideas, and discourses

\begin{tabular}{llll}
\hline Level & Ideas & Discourse & Actors \\
\hline Societal & $\begin{array}{l}\text { Normative background } \\
\text { ideas on the purpose of } \\
\text { schooling }\end{array}$ & $\begin{array}{l}\text { Communicative } \\
\text { discourse on a new } \\
\text { philosophy }\end{array}$ & $\begin{array}{l}\text { Ministry, Municipal } \\
\text { authorities, media }\end{array}$ \\
\hline Programmatic & $\begin{array}{l}\text { Cognitive foreground } \\
\text { ideas on competency- } \\
\text { based schooling }\end{array}$ & $\begin{array}{l}\text { Communicative dis- } \\
\text { course on the benefits of } \\
\text { the new curriculum }\end{array}$ & $\begin{array}{l}\text { Ministry, municipal } \\
\text { authorities, media }\end{array}$ \\
\hline $\begin{array}{l}\text { Municipal and } \\
\text { Classroom level }\end{array}$ & $\begin{array}{l}\text { Normative background } \\
\text { ideas on the meaning of } \\
\text { new curriculum }\end{array}$ & $\begin{array}{l}\text { Communicative dis- } \\
\text { course on knowledge } \\
\text { and skills }\end{array}$ & $\begin{array}{l}\text { Teacher educators, } \\
\text { directors, teachers }\end{array}$ \\
\hline
\end{tabular}

This framework provides a possibility to examine at the discourses and ideas at the societal, programmatic, and local levels (municipalities and schools). At the general societal level, the process of curriculum reform in Kosovo has been partly to help the nation define the real purpose of schooling. Kosovo, as a transitional society, has considered it necessary to place schools as tools for societal transformation and developing democracy, and this is reflected throughout the curriculum documents. The overarching theme of the 2011 curriculum policy ("MEST", 2011) has been characterised by the notion of developing workforce skills connecting the $21^{\text {st }}$-century skills (competencies) agenda, which overshadowed the dimension of values and attributes at the practical implementation level. The Kosovo education system was not resistant to the ever-increasing trend of following the human capital and skills development agenda advocated by key players, such as the OECD, World Bank and EU, pushed forward through various instruments, including the PISA student assessment programme. This tendency of comparing student achievement and education system indicators is also known as 'governing by number' (Grek, 2013) and is strongly reflected in the Curriculum Theory research supporting the orientation to the achievement of pre-determined learning outcomes as a key school function.

The Kosovo curriculum reform process has been characterised by normative background ideas aimed at ensuring a common understanding of the anticipated role of the school in society. The efforts were placed on defining, at the national level, a curriculum that drives forward the development of a skilled workforce. In essence, there is nothing wrong with such an agenda; it is more how the dimensions of nurturing values and developing attitudes among students are intertwined with such an economic development agenda. 
The challenges arose around developing a common understanding among key actors as to what the new value system implied for the societal and school levels. The policymakers decided on the new curriculum vision, and they chose a communicative discourse to present the idea to the school community and general public (regardless of the sporadic field consultations). The normative background mode of ideas was not very strong, however. During the stage of conceptualising the 2011 curriculum policy, the focus was more on the implementation level of the curriculum rather than placing the debate at a more conceptual level of what values and aspirations the curriculum is serving. Such a conclusion is reached given the scant and general-level instructions and processes made available to make sure the new policy is transferred at the classroom level in the desired way. In such a situation, when the communicative discourse is placed at a general level and focused on how to deliver a competency-based curriculum, the reform is superficially understood and simplified to determining a set of new teaching techniques and strategies that will support curriculum implementation. This happens due to a failure to embed the reform vision at a broader societal level, which related to how people see the purpose of schooling and the values that drive it.

At the programmatic level, the Kosovo curriculum reform reflected a greater focus on the cognitive foreground ideas and a stronger emphasis on communicative discourse. The public and educators needed to adequately understand what this new role of the school was and how it would translate into how schools and teachers need to behave in the new professionalism. In particular, parents are key stakeholders able to support the reform ideas forward either through working with their children or through their roles in the school. Similarly, the media failed to play their role effectively in the communicative discourse in linking the educators, administrators, and the public on the meaning of new policy intentions and implications. The media paid attention to education reform only during the election campaign in so far as it was connected to the reform and quality at a general level. The ministry, municipal authorities, and school directors adopted the communicative discourse to clarify programmatic ideas related to the meaning and purposes of the new curriculum. This communicative discourse also entailed instructional guidance for teachers.

The municipal and school level has been grouped as one local level due to the specifics of the education context. Though municipalities are granted, according to legislation, the responsibility for the delivery and organisation of instruction in schools, still they are a quite passive actor in education development. They play a rather administrative role, and this is a part of the problem. Under the current circumstances, delivering the new curriculum in the Kosovo 
school system is still considered an end in itself rather than means to an end (for this concept, see Young, 2008). The focus has been predominantly placed on the background normative ideas as to what the curriculum philosophy is about and what it means for the teacher practice rather than how it is translated into individual students. In addition, the practice of the recent curriculum reform has been characterised by a communicative discourse from the levels of ministry to teacher educators and down to schools on the meaning of the new curriculum in practice. There has been a lack of coordinative discourse at the level of helping the school community define the new meaning of teaching that the new curriculum is advocating, which is usually done through professional development activities.

Professional development is key to implementing curriculum reform (Chan, 2010). Within the package of the 2011 curriculum reform project in Kosovo, teachers and school directors were supported through a five-day seminar offered by the Ministry of Education as a form of developing a common understanding of new curriculum approach. The professional development support provided cannot be criticised on how it was delivered, but rather what was offered, the objectives that this served, and the volume of support provided to school directors and teachers. The professional development support offered to schools was in the form of conventional training workshops along with the instructions and guidelines for curriculum implementation. Thus, it is not the quality of workshops that is to be improved. Instead, it needs to be acknowledged that in such major curriculum transformations that target the conceptual level of the role of schooling, a school community needs more time and activities at the school level to internalise and make their interpretations of what the new curriculum is about. This requires sufficient time and input to internalise the reform goals, and the best way to provide this is by involving schools in developing their own coordinative discourse.

This brings us to the point of recognising the importance of how a school system is organised and managed. The school autonomy and the level of initiatives and development activities at school is an essential element in ensuring both communicative and coordinative discourse levels that occur within curriculum reform implementation. Though this should be a regular activity of teacher professional learning communities and joint planning activities, when a new curriculum reform is introduced, it implies the need that school directors and teachers engage in more focused activities to interpret the meaning of certain reform elements into practice. In the Kosovo curriculum reform example, it appeared that policymakers and school communities considered as sufficient the instructions and interpretations determined at the central expert 
and administrator level as to what the new curriculum is about. Focusing on coordinative discourse is key to the implementation of reform ideas in education contexts that are challenging in terms of capacities and expertise at the school level. Given that teacher professionalism in the Kosovo education system needs improvement (Saqipi, 2014; Saqipi \& Vogrinc, 2017), the need arises for more coordinative discourse in implementing reform so that teachers engage in their own interpretations and understanding of the reform ideas for educational practice. After all, in order for the reform ideas to succeed, it is critical that all actors in curriculum implementation share a common understanding of reform ideas.

Within the process of determining the meaning and practice of the new curriculum policy (communicative discourse for normative foreground ideas), the government established in addition to the curriculum framework also core curricula that detail the topics to be taught to students at various levels as well as the learning outcomes expected at various stages. Furthermore, the instructions on teaching methodologies and assessment strategies to be adopted for the new curriculum have also been detailed centrally by the government. This was all meant to help teachers best contribute to the development of the skills and knowledge deemed relevant for the Kosovar youth. The tendency of the Kosovo education system is to move towards decentralising education competencies (See "MEST", 2016), including greater school autonomy. Implementing curriculum is one of the key areas in which schools can be empowered to take initiatives (See Beatriz et al., 2008; Mona et al., 2011) and school autonomy increased. So, taking a centralised approach to detailing topics, suggesting teaching methodologies and, more importantly, making interpretation of the key principles and practices in curriculum implementation is a measure that goes against the empowerment and decentralisation agenda. Also, the communicative discourse in such a context does not suffice, and the education system needs to empower the coordinative discourse as a tool to link the school community to the new philosophy of teaching and schooling advocated.

The importance of ideas and discourse is closely linked to the need of seeing institutions not as rule-following constructs, while institutional change as dynamic and norms as dynamic constructs (Schmidt, 2008). The three elements require a good mix of communicative and coordinative discourse. The difference is made by the professional capacities of key actors, and when speaking about curriculum reform, the professionalism of teachers becomes critical. Teacher pedagogical thinking and practice are key to determining how the institution treats the reform inputs. In order to ensure a dynamic and meaningmaking orientation to policy inputs, centralised approaches and prescribed 
curricula do not provide for sufficient coordinative discourse to internalise such inputs. The Kosovo curriculum reform did not manage to take the curriculum reform debate to this level. The debate remained at the general level of deciding what the new policy is and how it should be best implemented. All the specifics of interpreting the norms and meaning-making processes were overshadowed by the high focus on a set of pre-determined skills, which should only serve as reference points to the complex task of teachers in current societies to look at teaching as a complex and dynamic activity.

\section{Understanding the importance of the curriculum imple- mentation context}

Developing contexts and transitional societies are greatly influenced by policy transfer from more developed economies of the world, and this naturally translates in how the national curricula are shaped. This phenomenon has been strongly evident in the Kosovo curriculum design project in the last two decades. The 2011 reform predominantly reflected the inclination to connect the European Union competencies for the $21^{\text {st }}$ century, making these a central theme of the curriculum package. It is evident in the current context of globalisation that curriculum reform projects in Kosovo are not exempt from the policy transfer phenomenon. Kosovo's participation in the international assessments and the path towards European integration as well as the inclination to place education at the service of economic development will likely continue to increase motivation in the education system to engage in transnational policy transfer.

However, regardless of how countries engage with transnational policy flow and the dynamics of the reform projects, it is essential for education systems to pay due attention to the purpose the curriculum and its actual delivery are serving. As Lundgren (2015) refers to how Herbart elaborated three different ways of teaching:

One of education without teaching, in which teachers educate with disciplinary methods, another is teaching without education, where the student is a passive receiver, and there is a third possibility, education by teaching, where the process will take place as a formation (Bildung) of the child directed towards dealing with an unknown future. (p. 7)

After all, the latter is what matters in current societies while putting curriculum reform into service, and preparing the context to support this goal is the responsibility of education policymakers and enactors at the level of 
planning and experiencing curriculum. Furthermore, the example of Kosovo curriculum reform indicated the need to ensure a consistent approach between the type of ideas communicated and the discourses used to communicate those ideas in a particular context, which proved to play a pivotal role in what happens in schools.

It is critical that curriculum reform is supported by the context in which it is implemented, and the analysis of Kosovo curriculum reform projects has demonstrated the importance that is attached to this as a prerequisite for the reform ideas to succeed. Kosovo's experience showed that while trying to address the conceptual level of curriculum to change the school system, it may happen that at a practical level the curriculum development ends up being seen as an end in itself. Thus, any education system needs to address the implementation approach to curriculum reform (Chan, 2010). The Kosovo experience reflected the approach of normative background ideas and placed the focus and priority on communicative discourse under a centralised mode of functioning. Given the need for the public and the school community to be mobilised for the reform introduced, the communicative discourse was more easily managed within the time and resources available in Kosovo circumstances. The curriculum vision to develop skills for the economy in Kosovo was not sufficiently processed and internalised by all policy enactors as a result of lack of more substantial communicative discourse and almost missing coordinative discourse between policy enactors. Given the acknowledged challenges of Kosovo student learning (see "MEST", 2016; OECD, 2016), the implementation process of Kosovo curriculum reform has failed to address the level of teacher pedagogical thinking, their preparedness, and commitment, which should have been an important theme in the decisions around the types of ideas and discourses applied during the reform projects. Furthermore, knowing the traditional knowledgeoriented education system culture, not addressing these critical context variables would certainly lead to the same low results of student performance despite the innovative expectations of the new curriculum.

\section{Conclusion}

Though curriculum policy in any education system generally advocates the idea of developing democracy, as well as the societal values and skills needed for current societies, it is necessary to recognise the choices education systems make in conceptualising and operationalising the curriculum. The critical part is thus deciding the nature of ideas to be pushed forward and discourses adopted for that purpose. The Kosovo curriculum reform had a strong focus on 
the achievement of pre-determined skills overshadowing a broader perspective of curriculum goals in terms of values and attributes aspired for new generations. Partly, this relates to the choice of discourse in pushing the ideas forward as well as due to the inclinations to absorb the principles of the Curriculum Theory as a general international benchmark that was adopted without any critical reflection. Weak communicative discourse in defining the real meaning and purpose of the curriculum policy and a lack of foreground types of ideas have significantly influenced the level of support that can be generated in promoting professionalism in the teaching profession. This article concluded that when a curriculum reform is ambitious and professional capacities in the school system limited, education systems are faced with the risk of not ensuring sufficient coordinative discourse to serve the purpose of proper understanding and internalising the reform objectives.

One important contextual variable in deciding the adequate forms and means of pushing ideas forward is the way schools are managed and the organisational culture they reflect. This is important for operationalising curricula and ensuring that the school community develops an adequate understanding of the ideas promoted. Hence, policymakers and policy enactors need to acknowledge the new meaning of context by assigning adequate value to the time spent on reform planning and implementation, as well as determining a realistic ambition for the reform. As regards reform planning, education systems in transition face difficulties in deciding between what models to follow when shaping a curriculum policy and lack capacities to internalise the inputs that derive from various models they chose to study or that come to them within the package of technical assistance through the intervention of donor partners.

Determining a true meaning of contextual variables and reaching a coherence between the ideas the reform promotes and deciding the right balance between communicative and coordinative discourse are key to making curriculum reform a driver of changing teacher professional practice. In addition to addressing professional capacities in the school system, policymakers and enactors need to recognise the curriculum tradition of the particular education system and the evolution of the curriculum tradition from a historical perspective. For the curriculum to serve its multiple goals of skills and values agenda, it is critical that education systems are pushed away from practices of 'curriculumas-manual' (Autio, 2014) and seeing learning only as something to be measured and quantified. Therefore, the key to success is how to use the capacity building as a tool to place context at the service of reform implementation in order to move policy enactors towards the desired professionalism through the application of adequate communicative and coordinative discourse. Introducing 
innovations requires a new approach to reform in cases the traditional way proved unsuccessful. Doing 'more-of-the-same' will not suffice. Once a successful reform project is implemented, it will safeguard a successful reform implementation model for the system. One important assumption is that the system makes the right and evidence-based choice for curriculum policy orientation following a critical review of models being considered.

\section{References}

Anderson-Levitt, K. M. (2008). The discursive side of new institutionalism. Cultural Sociology, 9(2), $162-184$.

Autio, T. (2014). The internationalization of curriculum research. In W. F. Pinar (Ed.), International handbook of curriculum research (pp. 17-31). New York, NY: Taylor and Francis.

Beatriz, P., Deborah, N., \& Hunter, M. (2008). Improving school leadership: Policy and Practice. Paris: OECD. Retrieved from http://www.oecd.org/education/preschoolandschool/44374889.pdf

Brouwer, N., \& Korthagen, F. (2005). Can teacher education make a difference? American Educational Research Journal, 42(1)153-224.

Chan, J. K. S. (2010). Teachers' response to curriculum policy implementation: colonial constraints for curriculum reform. Education Research for Policy and Practice, 9(2), 93-106.

Darling-Hammond, L. (2000). How teacher education matters. Journal of Teacher Education, 51(3), $166-173$.

Day, C. (2002). School reform and transition in teacher professionalism and identity. International Journal of Educational Research, 37(8), 677-692.

Goodlad, J. I., Klein, M. F., \& Tye, K. A. (1979). The domains of curriculum and their study. In J. I. Goodlad (Ed.), Curriculum inquiry (pp. 43-76). New York, NY: McGraw-Hill.

Grek, S. (2013). Expert Moves: International comparative testing and the rise of expertocracy. Journal of Education Policy, 28(5), 695-709.

Hargreaves, A., \& Shirley, D. (2009). The fourth way: Inspiring future of educational change. London, UK: Sage.

Helsby, G. (1996). Defining and developing professionalism in English secondary schools. Journal of Education for Teaching, 22(2), 135-148.

Hopmann, S., \& Riquarts, K. (2000). Starting a dialogue: A beginning conversation between the Didaktik and curriculum traditions. In I. Westbury, S. Hopmann, \& K. Riquarts (Eds.), Teaching as a reflective practice: The German Didaktik tradition (pp. 3-11). Mahwah, NJ: Lawrence Erlbaum. Hopmann, S. (2007). Restrained Teaching: The common core of Didaktik. European Educational Research Journal, 6(2), 109-124.

Huang, T. (2016). Integrating the ontological, epistemological and sociocultural aspects: A holistic view of teacher education. Teachers and Teaching 22(8), 947-964.

Lundgren, U. (2015) When curriculum theory came to Sweden. Nordic Journal of Studies in 
Educational Policy, 2015, (1). doi:10.3402/nstep.v1.27000

Mona M., Chinezi Ch., \& Michael B. (2011). How do world's most improved systems keep getting better? New York, NY: McKinsey \& Company.

Ministry of Education, Science and Technology (MEST). (2001). Kosovo curriculum framework.

Prishtina: MEST.

Ministry of Education, Science and Technology (MEST). (2011). Kosovo curriculum framework.

Prishtina: MEST.

Ministry of Education, Science and Technology (MEST). (2016). Kosovo education strategic plan.

Prishtina: MEST.

Organization for Cooperation and Economic Development in Europe (OECD). (2016). PISA results in focus. Paris: OECD.

Sahlberg, P. (2011). The fourth way of Finland. Journal of Educational Change, 12(2), 173-185.

Salhberg, P. (2007). Education policies for raising student learning: The Finnish approach. Journal of Education Policy, 22(2), 147-171.

Saqipi, B. (2019). Teacher education policy discourse in the midst of system reorganisation and policy transfer: Lessons for small and developing countries. International Journal of Management in Education, 13(1), 28-39.

Saqipi, B. (2014). Developing teacher professionalism and identity in the midst of large-scale education reform - the case of Kosovo (Doctoral dissertation). Jyvaskyla: University of Jyvaskyla. Saqipi, B., \& Vogrinc, J. (Eds.) (2017). The prospects of reforming teacher education. Prishtina: Libri Shkollor.

Schmidt, V. (2008). Discursive institutionalism: The explanatory power of ideas and discourse. Annual Review of Political Science, 11(1),303-326.

Schmidt, V. (2009). Putting the political back into political economy by bringing the state back in yet again. World Politics, 61(3), 516-546.

Schmidt, V. (2010). Taking ideas and discourse seriously: Explaining change through discursive institutionalism as the fourth 'new institutionalism'. European Political Science Review, 2(1), 1-25. Smeed, J., Bourke, T., Julie, N., \& Corsbie, T. (2015). Testing time for the implementation of curriculum change: analysis and extension of a curriculum change model. Sage Open, 5(2), 1-14. Steiner-Khamsi, G. (2012). Understanding policy borrowing and lending. In G. Steiner-Khamsi \& F. Waldow (Eds.), World yearbook of education 2012: Policy borrowing and lending in education. New York, NY: Routledge.

Tahirsylaj, A. (2018). Curriculum reform as a political statement in developing contexts: A discursive and non-affirmative approach. Transnational Curriculum Inquiry, 15(2), 38-49. Retrieved from https://ojs.library.ubc.ca/index.php/tci/index

Tahirsylaj, A. (2018b). Teacher autonomy and responsibility variation and association with student performance in Didaktik and curriculum traditions. Journal of Curriculum Studies, 51(2), 162-184. doi:10.1080/00220272.2018.1535667

Wahlstrom, N., \& Sundberg, D. (2017). Discursive institutionalism: Towards a framework of 
analysing the relation between policy and curriculum. Journal of Education Policy, 33(1), 163-183. Westbury, I. (2000). Teaching as a reflective practice: What might Didaktik teach curriculum? In I. Westbury, S. Hpmann, \& K. Riquarts (Eds.), Teaching as a reflective practice: The German Didaktik tradition. New Jersey, NJ: Lawrence Erbalum Associates.

Westbury, I. (2000). Teaching and reflective practice: The German Didaktik Tradition. New Jersey, NJ:

Lawrence Erbalum Associates.

Young, M. (2008). Bringing knowledge back in: From social constructivism to social realism in the sociology of education. London, UK: Routledge.

\section{Biographical note}

BLERIM SAQIPI, PhD, is assistant professor at the University of Prishtina's Faculty of Education in Kosovo. He holds $\mathrm{PhD}$ in Education and teaches courses on educational change, teacher development and research methods. His research interest is focused on the development of teacher professionalism as it relates to the social and educational context. In addition, his research is focused on understanding the phenomena of comparison and policy transfer in small and developing education systems with an emphasis on teacher education policy and practice. 